\title{
Different spectrophotometric methods applied for simultaneous analysis of binary mixture of formoterol and fluticasone: a comparative study
}

\begin{abstract}
The quantitative analysis is of an interesting issue for the analytical chemistry especially if the compounds of interest have been analyzed in term of sensitivity, low cost, without previous separation and saving analysis time; in this article simultaneous quantitative analysis of binary mixture of formoterol and fluticasone by four different spectrophotometric methods have been discussed and compared these methods namely, simultaneous equation, graphical absorbance ratio, absorbance subtraction and amplitude modulation. The proposed methods were simple, sensitive, accurate and precise. They do not need any sophisticated apparatus and could be easily applied in quality control laboratories. Linearity of the proposed methods was investigated in the range of $2-14 \mu \mathrm{g} / \mathrm{ml}$ for formoterol and $5-40 \mu \mathrm{g} / \mathrm{ml}$ for fluticasone. All the methods were validated according to the ICH guidelines, statistically compared with a reported method.Another statistical comparison of the obtained results by the proposed methods and the reported method were done using one-way ANOVA test. According to the results obtained by applying these methods there is no significant difference between all of them.
\end{abstract}

Keywords: formoterol, fluticasone, simultaneous equation, graphical absorbance ratio, absorbance subtraction; amplitude modulation
Volume 7 Issue 2 - 2018

\section{Nasr Mohamed A El-Abasawy, Khalid Abdel- Salam MAttia,Ahmed A Abouserie, Ahmed El-Olemy, Ayman Osman Elsayed \\ Department of Pharmaceutical Analytical Chemistry,Al-Azhar} University, Egypt

Correspondence: Ayman Osman Elsayed, Department of Pharmaceutical Analytical Chemistry, Faculty of Pharmacy, Al-Azhar University, I I75 I Nasr City, Cairo, Egypt, Tel +20 I000785052,Email ayman_phd20I5@yahoo.com

Received: February 20, 2018 | Published: April 09, 2018

\section{Introduction}

Formoterol fumarate dihydrate is N-[2-Hydroxy-5-(1-hydroxy2-\{[2-(4methoxyphenyl)-1-methylethyl] amino\} ethyl) phenyl] formamide fumarate, (Figure 1). It's a fine white powder soluble in water and methanol; slightly soluble in ethanol and chloroform with a molecular formula $\mathrm{C} 42 \mathrm{H} 56 \mathrm{~N} 4 \mathrm{O} 14$ and molecular weight $840.92 .{ }^{1}$ Formoterol is a long-acting beta2-agonist used in the management of asthma and/or chronic obstructive pulmonary disease. ${ }^{2}$ Fluticasone propionate is S-(fluoromethyl)-6 $\alpha, 9$-difluoro-11 $\beta, 17$-dihydroxy-16 $\alpha$ methyl-3-oxoandrosta-1,4-diene-17 $\beta$-carbothioate, 17 propanoate (Figure 2). It's a white powder practically insoluble in water, freely soluble in dimethyl sulfoxide (DMSO) and dimethyl formamide (DMF); slightly soluble in methanol and $95 \%$ ethanol with a molecular formula $\mathrm{C}_{25} \mathrm{H}_{31} \mathrm{~F}_{3} \mathrm{O}_{5} \mathrm{~S}$ and molecular weight $500.58 .{ }^{1}$ It's a synthetic trifluorinated glucocorticoid receptor agonist with anti-allergic, antiinflammatory used as powder or aerosol inhalation for the prophylaxis of asthma and treatment of allergic rhinitis. ${ }^{2}$ Flutiform is an inhaler (a pressurized inhalation, suspension) which contains two active ingredients; Formoterol fumarate dihydrate and fluticasone propionate, together these two active ingredients helps to prevent breathing problems such as asthma and helps to stop breathless and wheezing. ${ }^{3}$ There are few reported chromatographic methods for analysis of both components simultaneously; these were high-performance liquidchromatography ${ }^{4-6}$ and thin layer chromatography ${ }^{7}$ but to date there is no reported UV spectrophotometric method for simultaneous determination of formoterol and fluticasone.<smiles>COc1ccc(C[C@H](C)NC[C@H](O)c2ccc(O)c(NC(=O)O)c2)cc1</smiles>

Figure I Structural formula of formoterol fumarate dehydrate.

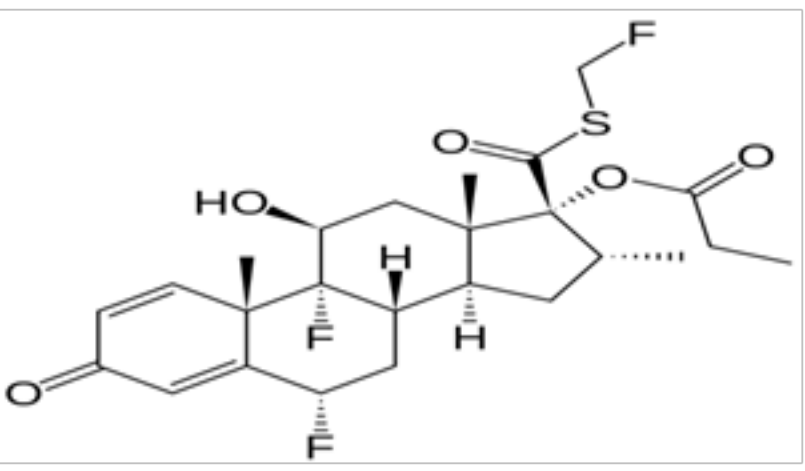

Figure 2 Structural formula of Fluticasone propionate. 
In the present work, a comparative study using one-way ANOVA test was done between four methods as first reported spectrophotometric methods for the simultaneous determination of formoterol and fluticasone; namely simultaneous equation, ${ }^{8-11}$ graphical absorbance ratio, ${ }^{12-14}$ absorbance subtraction ${ }^{15,16}$ and amplitude modulation. ${ }^{17,18}$

\section{Experiment}

\section{Instruments}

SHIMADZU dual beam UV-visible spectrophotometer (Kyoto/ Japan), model UV-1650PC connected to IBM compatible and a HP1020 LaserJet printer. The bundled software, UV-Probe personal spectroscopy software version 2.21 (Shimadzu) was used. The spectral band was $2 \mathrm{~nm}$ and scanning speed was is $2800 \mathrm{~nm} / \mathrm{min}$ with $0.2 \mathrm{~nm}$ interval.

\section{Materials}

\section{Pure samples}

a. Pure formoterol $(99.60 \%)$ was kindly supplied by GlaxoSmithKline (GSK) Company, Egypt.

b. Pure fluticasone (99.75\%) was kindly supplied by GlaxoSmithKline (GSK) Company, Egypt.

\section{Pharmaceutical preparation}

Flutiform ${ }^{\circledR}$ inhaler: Pressurized inhalation labeled to contain 120 inhalations each inhalation contains $5 \mu \mathrm{g}$ of formoterol and $50 \mu \mathrm{g}$ of fluticasone (B.No. 6H185FR), manufactured by Fisons company, United Kingdom), purchased from local market.

\section{Chemicals and reagents}

Methanol; was procured from El-Nasr Company, Egypt Methanol, analytical grade (El-Nasr Company, Egypt).

\section{Standard solutions}

Standard solution of formoterol: A standard solution of formoterol $(100 \mu \mathrm{g} / \mathrm{mL})$ was prepared by transferring $10 \mathrm{mg}$ of the drug powder to $100 \mathrm{ml}$ volumetric flask, dissolving in $50 \mathrm{ml}$ of methanol and completed to $100 \mathrm{ml}$ with the same solvent.

Standard solution of fluticasone: A standard solution of fluticasone $(100 \mu \mathrm{g} / \mathrm{mL})$ was prepared by transferring $10 \mathrm{mg}$ of the drug powder to $100-\mathrm{ml}$ volumetric flask, dissolving in $50 \mathrm{ml}$ of methanol and completed to $100 \mathrm{ml}$ with the same solvent.

\section{Procedures}

\section{Linearity and construction of calibration curves}

Simultaneous equation method: Different aliquots equivalent to $(20-140) \mu \mathrm{g}$ of formoterol and $(50-400) \mu \mathrm{g}$ of fluticasone were accurately transferred from their standard solutions $(100 \mu \mathrm{g} / \mathrm{ml})$ into two separate series of $10 \mathrm{ml}$ volumetric flasks and completed to volume with methanol. The absorption spectra (from 200 to $400 \mathrm{~nm}$ ) of these solutions were recorded using methanol as a blank. The absorptivity is calculated for formoterol and fluticasone at $214 \mathrm{~nm}$ and $236 \mathrm{~nm}$.

Graphical absorbance ratio method: The zero order spectra was obtained as mentioned in simultaneous equation method. The absorbance values at $232 \mathrm{~nm}$ ( $\lambda$ iso) and $214 \mathrm{~nm}$ ( $\lambda \max$ of formoterol) were measured from which the absorptivity values for both drugs at the selected wavelengths were calculated.

Absorbance subtraction method: The zero order spectra was obtained as mentioned in simultaneous equation method. The absorbance values of both drugs at $232 \mathrm{~nm}$ (isoabsorptive point) and the absorbance values of formoterol at $286 \mathrm{~nm}(\lambda 2)$ were recorded. , then the absorbance factor of formoterol at $232 \mathrm{~nm}$ and $286 \mathrm{~nm}$ $[=$ A232/A286] was calculated.

Amplitude modulation method: The zero order spectra was obtained as mentioned in simultaneous equation method. The amplitude of ratio spectra for fluticasone and formoterol at isoabsorptive point $232 \mathrm{~nm}$ and $286 \mathrm{~nm}$ were recorded respectively.

Application to laboratory prepared mixtures: Accurate aliquots of formoterol and fluticasone were transferred from their working solutions into a series of $10 \mathrm{ml}$ volumetric flasks to prepare mixtures containing different ratios of both. The volumes were completed with methanol.with the solvent. The spectra of the prepared series from 200 to $400 \mathrm{~nm}$ were recorded and stored. The concentrations of both drugs were calculated for each proposed method.

Procedure for pharmaceutical preparation: Contents of one device of Flutiform ${ }^{\circledR}$ inhaler equivalent to 120 inhalations each inhalation contains $5 \mu \mathrm{g}$ of formoterol and $50 \mu \mathrm{g}$ of fluticasone were sprayed into a beaker containing $50 \mathrm{ml}$ of methanol. A portion equivalent to 0.5 $\mathrm{mg}$ of formoterol and $5 \mathrm{mg}$ of fluticasone were transferred to $100 \mathrm{ml}$ volumetric flask, the volume was made up to the mark with the same solvent to get a stock solution labeled to containing $5 \mu \mathrm{g} / \mathrm{ml}$ of formoterol and $50 \mu \mathrm{g} / \mathrm{ml}$ of fluticasone. By using aliquots covering the working concentration ranges. The content of the inhaler were calculated using the mentioned general procedure for each method.

\section{Results and discussion}

The zero-order absorption spectra of formoterol and fluticasone show a certain degree of overlapping, with isoabsorptive point at $232 \mathrm{~nm}$ and formoterol is more extended in plateau region from 280$308 \mathrm{~nm}$ in which fluticasone has no absorbance, as shown in (Figure 3 ). The overlapping also does not permit direct determination of fluticasone in presence of formoterol which can be overcome using different manipulation methods for determination of both components without previous separation.

\section{Simultaneous equation method}

The $\lambda$ max of both formoterol and fluticasone were determined and it was found to be 214 and $236 \mathrm{~nm}$ respectively (Figure 4). Absorption value at these two wavelengths $(\lambda 1, \lambda 2)$ of formoterol and fluticasone in the concentration ranges of $2-14 \mu \mathrm{g} / \mathrm{mL}$ and $5-40 \mu \mathrm{g} /$ $\mathrm{mL}$ were calculated, respectively. The absorptivity of formoterol and fluticasone were calculated at each wavelength. The concentrations of formoterol and fluticasone can be obtained by applying Cramer's rule and matrices in Equations. (1) and (2). Concentration of formoterol and fluticasone were calculated according to the following equations:

$$
\begin{aligned}
& \boldsymbol{A}_{1}=0.0969 \boldsymbol{C}_{\text {form }}+0.0155 \boldsymbol{C}_{\text {flut }} \text { at } 214 \mathrm{~nm}\left(\lambda_{1}\right) \text { equation (1) } \\
& \boldsymbol{A}_{2}=0.0267 \boldsymbol{C}_{\text {form }}+0.0411 \boldsymbol{C}_{\text {flut }} \text { at } 236 \mathrm{~nm}\left(\lambda_{2}\right) \text { equation (2) }
\end{aligned}
$$

Where $C_{\text {form }}$ and $C_{\mathrm{fl} l u t}$ are the concentrations of formoterol and fluticasone in $\mu \mathrm{g} / \mathrm{mL}$, respectively. 0.0969 and 0.0267 are the absorptivity values of formoterol at $\left(\lambda_{1}\right)$ and $\left(\lambda_{2}\right)$, respectively. 0.0155 and 0.0411 are absorptivity values of fluticasone at $\left(\lambda_{1}\right)$ and $\left(\lambda_{2}\right)$, 
respectively. $\mathrm{A}_{1}$ and $\mathrm{A}_{2}$ are the absorption values of sample solutions at the wavelength range $\left(\lambda_{1}, \lambda_{2}\right)$, respectively. The proposed simultaneous equation method was successfully applied for the simultaneous determination of formoterol and fluticasone in their laboratory prepared mixtures with a high degree of accuracy. Therefore, the method is considered selective for determination of the studied drugs.

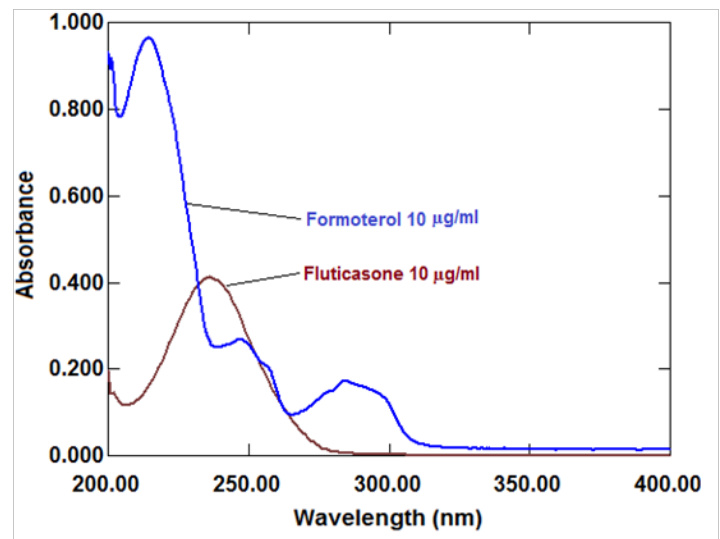

Figure 3 Zero-order absorption spectra of formoterol $(10 \mu g / m l)$, fluticasone propionate $(10 \mu \mathrm{g} / \mathrm{ml})$

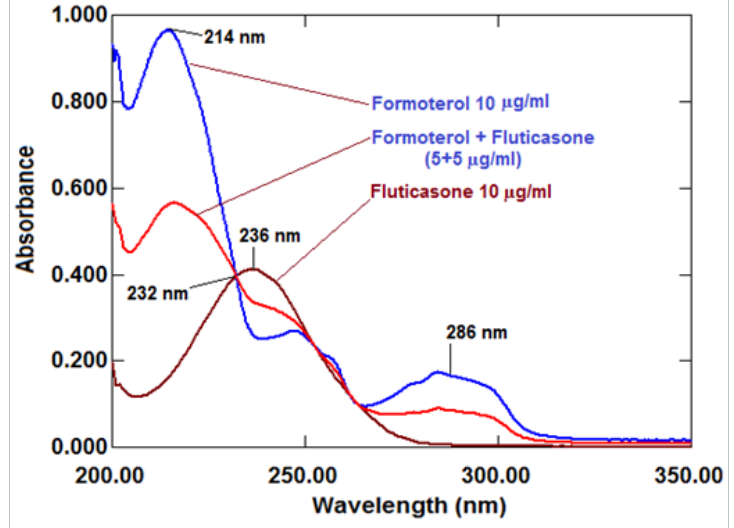

Figure 4 Zero-order absorption spectra of formoterol $(10 \mu \mathrm{g} / \mathrm{ml})$, fluticasone propionate $(10 \mu \mathrm{g} / \mathrm{ml})$ and their mixture $(5+5 \mu \mathrm{g} / \mathrm{ml})$ of each.

\section{Graphical absorbance ratio method}

In this method, the absorption spectra of $10 \mu \mathrm{g} / \mathrm{ml}$ formoterol, $10 \mu \mathrm{g} / \mathrm{ml}$ fluticasone, and of a mixture containing equal concentration of them $(5 \mu \mathrm{g} / \mathrm{ml}$ of each) showed isoabsorptive point at $232 \mathrm{~nm}$, as shown in (Figure 4). The spectra show also two isoabsorptive point at 252 and $263 \mathrm{~nm}$ which not involved in the proposed methods due to the low sensitivity of the drugs at these wavelengths. The absorbance values were measured at $214 \mathrm{~nm}(\lambda \max$ for formoterol) and $232 \mathrm{~nm}$ ( $\lambda$ iso) in the range of $2-14 \mu \mathrm{g} / \mathrm{ml}$ for formoterol and $5-40 \mu \mathrm{g} / \mathrm{ml}$ for fluticasone.

Absorptivity values were determined for each drug at two selected wavelengths and the average values were taken. The absorptivity and the absorbance ratio values were used to develop the sets of equations from which the concentration of both drugs in the sample can be calculated:

$$
\boldsymbol{C}_{\text {Formoterol }}=\left\{\left(\boldsymbol{Q}_{\boldsymbol{M}}-0.3953\right) /(2.3780-0.3953)\right\} \times\left(\boldsymbol{A}_{1} / 0.0408\right)
$$

$$
C_{\text {fluticasone }}=\left\{\left(\boldsymbol{Q}_{\boldsymbol{M}}-2.3780\right) /(0.3953-2.3780)\right\} \times\left(\boldsymbol{A}_{1} / 0.0393\right)
$$

Where,

$C_{\text {formoterol }}$ and $C_{\text {fluticasone }}$ are the concentrations of formoterol and fluticasone in $\mu \mathrm{g} / \mathrm{ml}$, respectively.

The value 2.3780 is the division of the mean absorptivity of formoterol at $214 \mathrm{~nm}$ over the mean absorptivity of the formoterol at $232 \mathrm{~nm}$.

The value 0.39535 is the division of the mean absorptivity of fluticasone at $214 \mathrm{~nm}$ over the mean absorptivity of fluticasone at $232 \mathrm{~nm}$.

The value 0.0408 is the mean absorptivity of formoterol at $232 \mathrm{~nm}$.

The value 0.0393 is the mean absorptivity of fluticasone at $232 \mathrm{~nm}$.

\section{Absorbance subtraction method}

In this method; absorbance factor of formoterol which is the average of the absorbance of different concentrations of formoterol using isoabsorptive point at $232 \mathrm{~nm}$ to that at $286 \mathrm{~nm}$ which shows no contribution of fluticasone [abs232/abs286] was used for calculating the absorbance values of formoterol and fluticasone at isoabsorptive point $(232 \mathrm{~nm})$ in their mixture as follow:

$$
\begin{aligned}
& \text { Absorbance of formolterol in the mixture at } t_{237}=\frac{a b s_{232}}{a b s_{286}} \times a b s_{286(\text { formoterol }+ \text { fluticasone })} \\
& \text { Absorbance of fluticasone in the mixture at } t_{232}=a b s_{232(\text { formoterol }+ \text { futicasone })}-\frac{a b s_{232}}{a b s_{286}} \times a b s \\
& 2866(\text { salmetrol }+ \text { fluticasone })
\end{aligned}
$$

Where, absi (formoterol + fluticasone) is the absorbance of the binary mixture at $232 \mathrm{~nm}$ or $286 \mathrm{~nm}$ and abs232/abs286 is the absorbance factor of pure formoterol at $232 \mathrm{~nm}$ to $286 \mathrm{~nm}$ and it was calculated and found to be 2.3993 . The calculated absorbance value corresponding to formoterol and fluticasone can be separately used to identify each of their concentration using the corresponding regression equations at isoabsorptive point $232 \mathrm{~nm}$.

\section{Amplitude modulation method}

In this method; by dividing the spectrum of the binary mixture by the normalized formoterol divisor spectrum, we obtain the ratio spectra as shown in (Figure 5). At the isoabsorptive point of ratio spectra the amplitude value was modulated to concentration. The amplitude value of the constant can be determined at the plateau region at $286 \mathrm{~nm}$, which is equal to the amplitude constant value of formoterol along the whole spectrum. At the isoabsorptive point $\left(\lambda_{\text {iso }}\right) 232 \mathrm{~nm}$, the amplitude of the ratio spectra at this point will be equal to the sum of the amplitudes of formoterol and fluticasone. After the subtracting recorded amplitude at $232 \mathrm{~nm}$ from the previously obtained constant at $286 \mathrm{~nm}$, we get the corresponding recorded amplitude of formoterol, which is equivalent to recorded concentration of formoterol in the mixture, while the recorded amplitude of constant value will be directly equal to the recorded concentration of fluticasone in the mixture. To eliminate any error due to signal to noise ratio, the actual concentration of formoterol and fluticasone could be calculated 
by using their corresponding regression equations at $286 \mathrm{~nm}$ and isosbestic point $232 \mathrm{~nm}$ respectively.

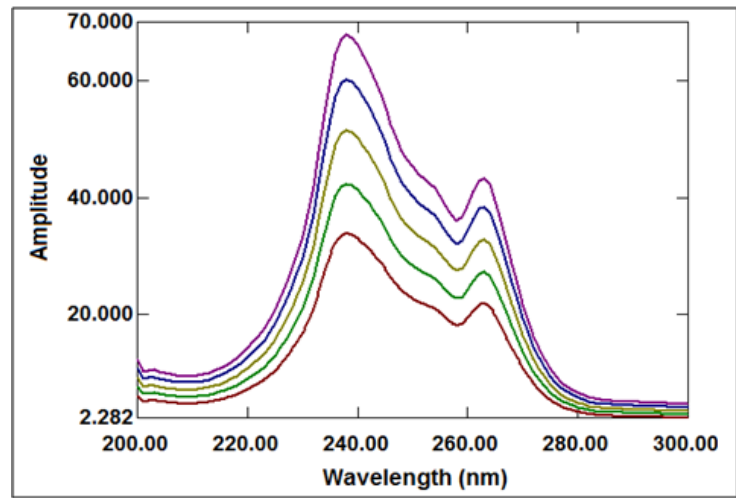

Figure 5 Division spectra of laboratory prepared mixtures $(2-4 \mu \mathrm{g} / \mathrm{ml})$ formoterol with $(20-40 \mu \mathrm{g} / \mathrm{ml})$ fluticasone using normalized spectrum of formoterol $(\mathrm{l} \mu \mathrm{g} / \mathrm{ml})$ as a divisor.

\section{Validation of the methods ${ }^{19,20}$}

Validation of the proposed methods was done according to ICH recommendations ${ }^{4}$ as shown in Table 1 . In which the limit of detection(LOD) and limit of quantitation (LOQ) were calculated from the following equations : $\mathrm{LOD}=3.3 \sigma / \mathrm{S} \& \mathrm{LOQ}=10 \sigma / \mathrm{S}$, Where $\sigma$ is the standard deviation of $\mathrm{y}$-intercepts of regression lines and $\mathrm{S}$ is the slope of the calibration curve. The accuracy of the method was calculated by measuring the mean percent recovery of three determinations for three concentration of the studied drugs. The precision of the developed method was checked by measuring percent relative standard deviation (\% RSD) of both drugs for three concentrations in the same day (repeatability) and in three days (intermediate precision). The obtained values confirming high precision of the methods. The selectivity of the proposed procedures was assessed by the analysis of laboratory prepared mixtures of both drugs as shown in Table 2. The validity of the proposed procedures is further assessed by applying the standard addition technique showing no interference from excipients. The results obtained were shown in Table 3 .

Table I Assay validation of the proposed method

\begin{tabular}{|c|c|c|c|c|c|c|c|c|}
\hline \multirow[t]{2}{*}{ Parameter } & \multicolumn{2}{|c|}{ Simultaneous equation } & \multicolumn{2}{|c|}{$\begin{array}{l}\text { Graphical absorbance } \\
\text { ratio }\end{array}$} & \multicolumn{2}{|c|}{ Absorbance subtraction } & \multicolumn{2}{|c|}{ Amplitude modulation } \\
\hline & Formoterol & Fluticasone & Formoterol & Fluticasone & Formoterol & Fluticasone & Formoterol & Fluticasone \\
\hline Accuracy $(\% \mathrm{R})^{\mathrm{a}}$ & 100.02 & 100.17 & 99.8 & 100.04 & 100.02 & 99.99 & 100.07 & 99.98 \\
\hline \multicolumn{9}{|l|}{ Precision } \\
\hline Repeatability (\%RSD) ${ }^{\mathrm{b}}$ & 0.805 & 0.451 & 0.443 & 0.646 & 0.509 & 0.615 & 0.545 & 0.38 \\
\hline $\begin{array}{l}\text { Intermediate precision } \\
(\% \text { RSD })^{c}\end{array}$ & 0.892 & 0.729 & 0.61 & 0.889 & 1.201 & 0.824 & 0.662 & 0.52 \\
\hline Linearity range $(\mu \mathrm{g} / \mathrm{mL}$ & $(2-14 \mu \mathrm{g} / \mathrm{mL})$ & $\begin{array}{l}(5-40 \mu g / \\
\mathrm{mL})\end{array}$ & $(2-14 \mu \mathrm{g} / \mathrm{mL})$ & $(5-40 \mu \mathrm{g} / \mathrm{mL})$ & $(2-14 \mu \mathrm{g} / \mathrm{mL})$ & $(5-40 \mu \mathrm{g} / \mathrm{mL})$ & $\begin{array}{l}(2-14 \mu g / \\
\mathrm{mL})\end{array}$ & $\begin{array}{l}(5-40 \mu g / \\
\mathrm{mL})\end{array}$ \\
\hline Regression Equation & $y=b x+a$ & $y=b x+a$ & $y=b x+a$ & $y=b x+a$ & $y=b x+a$ & $y=b x+a$ & $y=b x+a$ & $y=b x+a$ \\
\hline Slope(a) & 0.0972 & 0.0409 & 0.0409 & 0.0392 & 0.0171 & 0.0391 & 0.9948 & 0.9538 \\
\hline Intercept(b) & -0.0015 & 0.0012 & -0.0007 & 0.0007 & -0.0004 & 0.0011 & -0.0155 & 0.014 \\
\hline Regression coefficient $\left(r^{2}\right)$ & 0.9998 & 0.9997 & 0.9998 & 0.9997 & 0.9998 & 0.9998 & 0.9998 & 0.9997 \\
\hline $\operatorname{LOD}(\mu \mathrm{g} / \mathrm{mL})$ & 0.186 & 0.665 & 0.198 & 0.666 & 0.201 & 0.643 & 0.193 & 0.662 \\
\hline $\mathrm{LOQ}(\mu \mathrm{g} / \mathrm{mL})$ & 0.562 & 2.016 & 0.599 & 2.018 & 0.608 & 1.948 & 0.585 & 2.005 \\
\hline
\end{tabular}

${ }^{a}$ Average of three determinations for three concentrations $(4,8$, and $12 \mu \mathrm{g} / \mathrm{mL})$ and $(15,25$, and $35 \mu \mathrm{g} / \mathrm{mL})$ for formoterol and fluticasone respectively.

${ }^{b}$ The intraday $(n=3)$, average of three concentrations $(4,8$, and $12 \mu \mathrm{g} / \mathrm{mL})$ and $(15,25$, and $35 \mu \mathrm{g} / \mathrm{mL})$ for formoterol and fluticasone respectively.

${ }^{c}$ The interday $(\mathrm{n}=3)$, average of three concentrations $(4,8$, and $12 \mu \mathrm{g} / \mathrm{mL})$ and $(15,25$, and $35 \mu \mathrm{g} / \mathrm{mL})$ for formoterol and fluticasone respectively.

Table 2 Determination of formoterol and fluticasone in laboratory prepared mixtures by the proposed methods

\begin{tabular}{|c|c|c|c|c|c|c|c|c|c|}
\hline \multirow[t]{2}{*}{$\begin{array}{l}\text { Conc. of } \\
\text { formoterol } \\
(\mu \mathrm{g} / \mathrm{mL})\end{array}$} & \multirow[t]{2}{*}{$\begin{array}{l}\text { Conc. of } \\
\text { fluticasone } \\
(\mu \mathrm{g} / \mathrm{mL})\end{array}$} & \multicolumn{2}{|c|}{ Simultaneous equation } & \multicolumn{2}{|c|}{$\begin{array}{l}\text { Graphical absorbance } \\
\text { ratio }\end{array}$} & \multicolumn{2}{|c|}{ Absorbance subtraction } & \multicolumn{2}{|c|}{ Amplitude modulation } \\
\hline & & $\begin{array}{l}\text { \%Recovery of } \\
\text { formoterol }\end{array}$ & $\begin{array}{l}\text { \%Recovery } \\
\text { of } \\
\text { fluticasone }\end{array}$ & $\begin{array}{l}\text { \%Recovery } \\
\text { of } \\
\text { formoterol }\end{array}$ & $\begin{array}{l}\text { \%Recovery } \\
\text { of } \\
\text { fluticasone }\end{array}$ & $\begin{array}{l}\text { \%Recovery of } \\
\text { formoterol }\end{array}$ & $\begin{array}{l}\text { \%Recovery } \\
\text { of } \\
\text { fluticasone }\end{array}$ & $\begin{array}{l}\text { \%Recovery } \\
\text { of } \\
\text { formoterol }\end{array}$ & $\begin{array}{l}\text { \%Recovery of } \\
\text { fluticasone }\end{array}$ \\
\hline 2 & 20 & 100.63 & 99.13 & 98.43 & 99.28 & 100.34 & 99.48 & 99.06 & 101.61 \\
\hline 2.5 & 25 & 99.19 & 99.24 & 99.09 & 99.37 & 100.22 & 99.44 & 100.55 & 98.57 \\
\hline 3 & 30 & 100.04 & 100.56 & 98.85 & 100.56 & 99.16 & $100.7 \mid$ & 98.69 & 100.21 \\
\hline 3.5 & 35 & 99.33 & 100.75 & 98.11 & 100.78 & $100.4 \mid$ & 100.97 & 99.45 & 99.85 \\
\hline 4 & 40 & 100.63 & 99.15 & 99.36 & 99.16 & 99.3 & 99.46 & 99.83 & 99.92 \\
\hline Mean \pm \%RD & & $99.96 \pm 0.688$ & $\begin{array}{l}99.77 \\
\pm 0.813\end{array}$ & $\begin{array}{l}98.77 \\
\pm 0.496 \\
\end{array}$ & $\begin{array}{l}99.83 \\
\pm 0.773 \\
\end{array}$ & $99.89 \pm 0.604$ & $\begin{array}{l}100.01 \\
\pm 0.762 \\
\end{array}$ & $\begin{array}{l}99.52 \\
\pm 0.715\end{array}$ & $100.03 \pm 1.085$ \\
\hline
\end{tabular}


Table 3 Recovery study of formoterol and fluticasone by adopting standard addition technique via the proposed methods

\begin{tabular}{|c|c|c|c|c|c|c|c|c|c|}
\hline \multicolumn{2}{|c|}{ Pure added $(\mu \mathrm{g} / \mathrm{ml})$} & \multicolumn{2}{|c|}{ Simultaneous equation } & \multicolumn{2}{|c|}{$\begin{array}{l}\text { Graphical absorbance } \\
\text { ratio }\end{array}$} & \multicolumn{2}{|c|}{ Absorbance subtraction } & \multicolumn{2}{|c|}{ Amplitude modulation } \\
\hline Formoterol & Fluticasone & $\begin{array}{l}\text { \%Recovery } \\
\text { of } \\
\text { formoterol }\end{array}$ & $\begin{array}{l}\text { \%Recovery } \\
\text { of } \\
\text { fluticasone }\end{array}$ & $\begin{array}{l}\text { \%Recovery } \\
\text { of } \\
\text { formoterol }\end{array}$ & $\begin{array}{l}\text { \%Recovery } \\
\text { of } \\
\text { fluticasone }\end{array}$ & $\begin{array}{l}\text { \%Recovery } \\
\text { of } \\
\text { formoterol }\end{array}$ & $\begin{array}{l}\text { \%Recovery } \\
\text { of } \\
\text { fluticasone }\end{array}$ & $\begin{array}{l}\text { \%Recovery } \\
\text { of } \\
\text { formoterol }\end{array}$ & $\begin{array}{l}\text { \% Recovery of } \\
\text { fluticasone }\end{array}$ \\
\hline 2 & 5 & 98.86 & 97.42 & 99.32 & 97.43 & 99.63 & 99.34 & 99.32 & 99.5 \\
\hline 3 & 10 & 99.75 & 99.16 & 99.2 & 99.18 & 99.02 & 99.16 & 100.83 & 101.02 \\
\hline 4 & 15 & 98.25 & 98.25 & 100.2 & 98.39 & 98.11 & 100.29 & 99.74 & 101.48 \\
\hline Mean $\pm \% R S D$ & & $98.95 \pm 0.746$ & $98.28 \pm 0.855$ & $99.57 \pm 0.544$ & $98.33 \pm 0.862$ & $98.92 \pm 0.757$ & $99.60 \pm 0.605$ & $\begin{array}{l}99.96 \\
\pm 0.779\end{array}$ & $100.67 \pm 1.043$ \\
\hline
\end{tabular}

\section{Statistical analysis ${ }^{21}$}

In order to compare the ability of the proposed methods for the simultaneous determination of formoterol and fluticasone in their pharmaceutical preparation, the results obtained by applying each of the proposed methods and the reported method ${ }^{13}$ were subjected to statistical analysis Table 4 . The calculated $t$ and $F$ values were less than the theoretical ones indicating that there were no significant differences between the proposed and the reported methods. Another statistical comparison of the results obtained by the proposed methods and the reported method for determination of formoterol and fluticasone in pharmaceutical product using one-way ANOVA test was shown in Table 5. The results obtained by applying these methods show no significant differences between all of them.

Table 4 Determination of formoterol and fluticasone by the proposed and reported methods

\begin{tabular}{|c|c|c|c|c|c|c|c|c|c|c|}
\hline \multirow{2}{*}{$\begin{array}{l}\text { Parameters } \\
\text { Drug }\end{array}$} & \multicolumn{2}{|c|}{$\begin{array}{l}\text { Simultaneous } \\
\text { equation }\end{array}$} & \multicolumn{2}{|c|}{$\begin{array}{l}\text { Graphical absorbance } \\
\text { ratio }\end{array}$} & \multicolumn{2}{|c|}{$\begin{array}{l}\text { Absorbance } \\
\text { subtraction }\end{array}$} & \multicolumn{2}{|c|}{$\begin{array}{l}\text { Amplitude } \\
\text { modulation }\end{array}$} & \multicolumn{2}{|c|}{ Reported method (4) } \\
\hline & formoterol & Fluticasone & formoterol & Fluticasone & formoterol & Fluticasone & formoterol & Fluticasone & formoterol & Fluticasone \\
\hline $\mathrm{n}^{*}$ & 5 & 5 & 5 & 5 & 5 & 5 & 5 & 5 & 5 & 5 \\
\hline $\begin{array}{l}\text { Average(\% } \\
\text { Recovery) }\end{array}$ & 99.87 & 99.83 & 100.11 & 99.93 & 99.45 & 100.01 & 100.03 & 100.05 & 99.71 & 99.37 \\
\hline$\%$ RSD & 0.833 & 0.969 & 0.945 & 0.921 & 0.645 & 0.857 & 0.625 & 0.953 & 1.029 & 1.014 \\
\hline $\mathrm{t}^{* *}(2.3 \mathrm{I})$ & 0.28 & 0.75 & 0.64 & 0.93 & 0.47 & 1.09 & 0.6 & I.I & -- & -- \\
\hline $\mathrm{F}^{* *}(6.39)$ & 1.52 & 1.08 & 1.18 & 1.2 & 2.25 & 1.38 & 2.69 & 1.12 & -- & -- \\
\hline
\end{tabular}

*Number of samples.

**The values in parenthesis are tabulated values of " $t$ "and " $F$ " at $(\mathrm{P}=0.05)$.

(4) HPLC using $\mathrm{C}_{18}$ column, mobile phase was phosphate buffer: acetonitrile [80:20 v/v], pH 3.5) at a flow rate (I mL/min) and UV detection at $215 \mathrm{~nm}$.

Table 5 One-way ANOVA test for the different proposed methods used for the determination of binary mixture of formoterol and fluticasone propionate in Flutiform® inhaler:

\begin{tabular}{llllll}
\hline Drug & Source of variation & Sum of squares & Degree of freedom & Mean of squares & F* $^{*}$ \\
\hline \multirow{2}{*}{ Formoterol } & Between groups & 1.377 & 4 & 0.344 & 0.5 \\
& Within groups & 13.77 & 20 & 0.689 & -2.87 \\
\multirow{2}{*}{ Fluticasone } & Between groups & 1.526 & 4 & 0.381 & 0.43 \\
& Within groups & 17.777 & 20 & 0.889 & -2.87 \\
\hline
\end{tabular}

*The value in parenthesis is the critical value of "F" at $(P=0.05)$

\section{Conclusion}

Four methods (simultaneous equation, graphical absorbance ratio, absorbance subtraction and amplitude modulation.) were presented as first reported spectrophotometric powerful methods for simultaneous determination and to resolve the overlapping of formoterol and fluticasone. The proposed methods were very simple with minimum manipulation steps, very sensitive, accurate and precise. They do not need any sophisticated apparatus and could be easily applied in quality control laboratories. 


\section{Acknowledgements}

Authors are deeply thankful to ALLAH, the Almighty, by the grace of whom this work was realized. Deep gratitude and appreciation to pharmaceutical analytical chemistry department, faculty of pharmacy Al Azhar University, for providing facilities and continuous support.

\section{Conflict of interest}

The author declares that there is no conflict of interest.

\section{References}

1. Windholz M, Budavari S, Stroumtsos LY, Fertig MN. An encyclopedia of chemicals and drugs. 13th ed. USA: The Merck index; 2001.

2. Goodman, Gillman's. The Pharmacological Basis of Therapeutics. 12th ed. USA; 2010.

3. https://www.drugs.com/uk/flutiform-50-microgram-5-microgram-peractuation-pressurised-inhalation-suspension-leaflet.html.

4. Gowekar NM, Wadher SJ. Simultaneous estimation of formoterol fumarate dihydrate and fluticasone propionatein dry powder inhalation formulation by RP-HPLC. Der Pharma Chemica. 2016; 8(5):27-32.

5. Priyank P Raval, JB Dave, Mittal P Joshi, et al. Estimation of fluticasone propionate in nasal preparation and in combination with formoterol fumarate in inhalation preparation. World journal of pharmacy and pharmaceutical science. 2014;3(6):1148-1160.

6. Kusum malik, Davinder kumar, Vivek tomar, et al. Simultaneous Quantitative Determination of Formoterol Fumarate and Fluticasone Propionate by Validated Reversed-Phase HPLC Method in Metered dose inhaler. Der Pharmacia Sinica. 2011;2(6):77-84.

7. Narendra M Gowekar, Shailesh J Wadher. Simultaneous Estimation of Formoterol Fumarate Dihydrate and Fluticasone Propionate in Dry Powder Inhalation Formulation by HPTLC. Der Pharma Chemica. 2016;8(5):27-32.

8. Chaudhary J, Jain A, Saini V. Simultaneous estimation of multicomponent formulations by UV-Visible spectroscopy: An overview. Int Res J Pharm. 2011;2(12):81-83

9. Sivadas A, Sathi A, Sathi K, et al. Development and validation of spectrophotometric methods for simultaneous estimation of citicoline and piracetam in tablet dosage form. J Pharm Bioallied Sci. 2013;5(3):202207.
10. Attia KA, Nassar MW, El-Zeiny MB, et al. Zero order and signal processing spectrophotometric techniques applied for resolving interference of metronidazole with ciprofloxacin in their pharmaceutical dosage form. Spectrochim Acta A Mol Biomol Spectrosc. 2016;154:232-236.

11. Soni H, Kothari C, Khatri D, et al. Simultaneous determination of atorvastatin calcium and olmesartan medoxomil in a pharmaceutical formulation by reversed phase high-performance liquid chromatography, high-performance thin-layer chromatography, and UV spectrophotometric methods. J AOAC Int. 2014;97(3):791-797.

12. Beckett AH, Stenlake JB. Practical Pharmaceutical Chemistry. 4th ed. New Delhi: CBS Publishers and Distributors; 1997.

13. Adelwahab NS. Spectrophotometric methods for simultaneous determination of carvedilol and hydrochlorothiazide in combined dosage form. Arabian Journal of Chemistry. 2016;9:355-360.

14. Bhusari KP, Khedekar PB, Dhole S, et al. Derivative and Q-analysis Spectrophotometric Methods for Estimation of Hydrochlorothiazide and Olmesartan Medoxomil in tablets. Indian J Pharm Sci. 2009;71(5):505508 .

15. Kelani KM, Shalaby AA, Elmaamly MY, et al. Spectrophotometric and chemometric methods for simultaneous determination of two antihypertensive drugs in their combined dosage form. Pharm Anal Acta. 2015;6(1):321-328.

16. Lotfy HM. Absorbance subtraction and amplitude modulation as novel spectrophotometric methods for the analysis of binary mixtures. Int $J$ Pharm Pharmaceut Sci. 2014;6(1):735-741.

17. Lotfy HM, Hegazy MA, Rezk MR, et al. Novel spectrophotometric methods for simultaneous determination of timolol and dorzolamide in their binary mixture. Spectrochim Acta A Mol Biomol Spectrosc. 2014;126:197-207.

18. Salem H, Mohamed D. A comparative study of smart spectrophotometric methods for simultaneous determination of a skeletal muscle relaxant and an analgesic in combined dosage form. Spectrochim Acta Part A. 2015;140(3):166-173.

19. Validation of analytical procedure: text and methodology Q2 (R1). International Conference on Harmonization. Geneva. 2005.

20. United States Pharmacopoeia 30 and National formulary 25. USA: United State Pharmacopoeia Convention. 2007.

21. Armitage P, Berry G. Statistical methods in medical research. 3rd ed Oxford (UK): Blackwell; 1994. 